\author{
Al-wardah: Jurnal Kajian Perempuan, Gender dan Agama \\ Volume : 13 No 1. Edisi Juni 2019 \\ ISSN: 1907-2740, E-ISSN: 2613-9367 \\ DOI: 10.46339/al-wardah.v13i1.156
}

\title{
FEMINISME DAN GERAKAN SOSIAL
}

\author{
Amin Bendar, \\ IAIN Ternate,Indonesia \\ email:bendar.amin@go.id
}

\begin{abstract}
Abstrak
Fokus Tulisan ini berupaya membawa perbedaan tersebut ke dalam keterbukaan untuk menunjukkan posisi subordinat kaum perempuan dan untuk menjelaskan sistem ekonomi dan politik dunia tidak mengistimewakan posisi perempuan. Feminisme dalam teori ini bisa dilihat sebagai proyek oleh kaum feminis untuk mempengaruhi perubahan sosial baik sebagai serangkaian penerapan maupun sebagai kumpulan teori. Feminisme mengadopsi gabungan tematik dan struktur kronologis, menyatukan koleksi karya tokoh-tokoh yang tak terbantahkan dalam proyek ini, serta penelitian penting dari generasi sarjana baru. Fokusnya kemudian akan membuka wacana kehidupan sosial pada tradisi teori sosial yang lebih luas dan peduli dengan studi tentang kekuatan sosial dan emansipasi manusia.
\end{abstract}

Kata Kunci : Feminisme ; Gerakan social

\begin{abstract}
Abstrac
Focus This paper seeks to bring these differences into openness to show the subordinate position of women and to explain the world economic and political system does not privilege the position of women. Feminism in this theory can be seen as a project by feminists to influence social change both as a series of applications and as a collection of theories. Feminism adopts a combination of thematic and chronological structures, bringing together a collection of works of irrefutable figures in this project, as well as important research from a new generation of scholars. The focus will then open the discourse of social life to the broader tradition of social theory and care about the study of social forces and human emancipation
\end{abstract}

Keywords: Feminism; Social movement . 


\section{A.Pendahuluan}

Perjuangan untuk menegakan keadilan dan kesetaraan hak antara laki-laki dan perempuan merupkan bagian dari problem sosial yang sampai saat ini menarik untuk dibicarakan. Dikatakan menarik karena hampir dalam setiap interaksi sosial yang terbangun di kalangan masyarakat, masih saja terjadi pola hubungan yang "menindas" terhadap perempuan.

Gambaran penindasan yang dialami kaum perempuan tersebut mendorong lahirnya berbagai gerakan sosial untuk memperjuangkan keadilan dan membebaskan kaum perempuan dari penindasan. Gerakan tersebut dikenal dengan nama gerakan feminisme. Gerakan ini sebenarnya telah lama dilakukan oleh kaum perempuan terutama di Eropa sejak abad ke -18, akan tetapi gerakan tersebut gerakan tersebut baru mencapai puncak di abad ke-20 yaitu tahun 1960-an

Gerakan feminisme ini dalam perkembangannya mengalami perubahan paradigma gerakan. Paradigma yang semula hanya memperjuangkan hak-hak kaum perempuan, kini berkembang menjadi sebuah perjuangan yang menuntut keadilan untuk seluruh manusia secara universal. Nighat Said Khan dan Kamla Bhasin menjelaskan bahwa feminisme tidak hanya bertujuan memperjuangkan persamaan laki-laki dan perempuan. Feminisme juga bertujuan membangun tatanan masyarakat yang bebas dari penindasan dan pengotakan berdasarkan kelas, kasta dan prasangka jenis kelamin.

Kesadaran akan pentingnya memperjuangkan keadilan universal ini mengalami perkembangan yang sangat pesat dan tersebar keseluruh dunia . Indonesia adalah wilayah yang tidak luput dari gerakan feminisme tersebut. Gerakan feminisme yang berkembang di Indonesia ini pada umumnya di lakukan dengan model terstruktur dalam sebuah lembaga atau organisasi keperempuanan. Jika dilihat dari keberadaannya lembaga perempuan di Indonesia ini telahn lama terbentuk, akan tetapi dalam 
perkembangannya di masa kekuasaan orde baru dengan kebijakan pembatasan keberadaan ormas-ormas dalam ruang politik menyebabkan seluruh organisasi gerakan termasuk organisasi keperempuanan mengalami masa surut dari permukaan.

Tumbangnya rezim orde baru ditahun 1998 merupakan era kebangkitan baru bagi lembaga keperempuanan yang memperjuangkan keadilan. Kehadiran lembaga keperempuanan di era reformasi ini di latarbelakangi oleh berbagai persoalan bangsa yang terjadi. keberadaan lembaga ini juga tidak terlepas dari berbagai pengaruh paham keagamaan maupun idiologi yang berkembang.

Sebagai bangsa yang mayoritas penduduknya memeluk agama Islam, maka hampir sebagian besar para feminis yang memperjuangkan keadilan juga adalah feminis muslim. Sejatinya feminis muslim tersebut dalam memperjuangkan keadilan harus menggunakan lembaga yang berciri khas muslim. Namun pada kenyataannya ada juga kecenderungan feminis muslim yang memilih lembaga non muslim atau lembaga umumj lainnya sebagai media pembelajaran.

Berangkat dari latar belakang tersebut, maka kam mengangkat tema naskah ini

\section{Feminisme dan gerakan Sosial}

Tujuan Penulisan ini adalah mendiskripsikan model gerakan feminsime sebagai gerakan sosial perempuan. sedangkanhasil yang diperoleh adalah secara teoritis dapat dijadikan bahan bacaan dalam memperkaya khasanah ilmu pengetahun di bidang sosial. secara prkatis kajian ini diharapkan dapat memberikan gambaran objectif tentang gerakan sosial feminisme yang ada sekarang ini.

\section{B. PEMBAHASAN}

\section{FEMINISME}

Feminisme berasl dari bahasa latin femina yang kemudian diterjemahkan kedalam bahasa Inggris menjadi Femine yang berarti memiliki sifat-sifat sebagai 
perempuan. Secara umum feminisme sering di defenisikan sebagai gerakan wanita yang menuntut persamaan hak antara kaum wanita dan pria. Kata feminisme ini dicetuskan pertama kali oleh aktivis sosial utopis ,

Charles Fourie

Teori feminisme di dasari oleh kebutuhan untuk memahami penyebab ketertindasan perempuan dengan tujuan untuk membalikkan tatanan sosial yang didominasi laki-laki. Diakhir tahun 1960-an dan awal tahun 1970-an, gerakan ini mengalami perkembangan yang luar biasa dan pada periode ini dikenal juga dengan nama periode kebangkitan feminsime gelombang kedua

Menurut Kristeva ada tiga gelombang atau tahapan feminisme yakni : Pada feminisme gelombang pertama, aliran feminisme mencakup di dalamnya lebih berfokus pada kesenjangan politik, terutama dalam memperjuangkan hak pilih perempuan atau emansipasi di bidang politik. Aliran feminisme awal ini dimulai pada tahun 1792-1960 yang bermula dari tulisan seorang filsuf dan feminis abad 18 bernama Mary Wollstonecraft. Dalam karyanya yang berjudul A Vindication of the Rights of Women, Mary Wollstonecraft menginspirasi gerakan dan perjuangan perempuan hingga berlanjut pada abad ke-20 dimana kaum perempuan berhasil mencapai hak pilihnya (hak politik). Dalam bukunya tersebut, ia menuliskan bahwa perempuan secara alamiah tidak lebih rendah dari laki-laki, tetapi terlihat seperti itu hanya karena mereka tidak memperolah banyak pendidikan. Ia mengusung supaya laki-laki dan perempuan dianggap setara dalam setiap dimensi kehidupan, terutama dalam hal sosial-politiknya..

Feminisme gelombang kedua lebih merupakan gerakan pembebasan perempuan atau biasa dikenal dengan istilah Women Liberation. Gerakan ini adalah gerakan kolektif yang revolusioner, sebagaimana nampak sejak kemunculannya pada tahun 1960 - 1980. Bisa dikatakan, inilah masa yang muncul sebagai reaksi kaum perempuan (feminis) atas ketidakpuasannya terhadap berbagai praktik diskriminasi. Terlebih diketahui bahwa secara hukum dan politis, hal ini sebenarnya telah dicapai oleh 
feminisme gelombang pertama tetapi dalam praktiknya tidak terealisasi secara maksimal.

Feminisme gelombang ketiga, atau dikenal juga sebagai posfeminisme. Aliran ini dimulai pada tahun 1980 sampai sekarang. Aliran ini begitu popular dan banyak dijadikan rujukan oleh para feminis modern. Meski demikian, banyak tokoh feminis yang menganggap bahwa feminisme gelombang ketiga berbeda dengan posfeminisme. Hal ini disebabkan karena posfeminisme merupakan gerakan yang menolak gagasan feminis gelombang kedua. Dilihat dari ide dan gagasannya misalnya, feminisme gelombang ketiga mengusung keragaman dan perubahan seperti globalisasi, postkolonialisme, poststrukturalisme, dan postmodernisme. Dalam hal ini, feminisme gelombang ketiga sangat dipengaruhi oleh postmodernisme yang merupakan pencetus lahirnya feminisme gelombang ketiga. Menurut Lyotard dan Vattimo, pengaruh postmodernisme terhadap feminisme gelombang ketiga dapat dilihat dari empat ciri. Keempat cirri tersebut, seperti menawarkan pendekatan revolusioner pada studi-studi sosial (mempertanyakan validitas ilmu pengetahuan modern dan anggapan adanya pengetahuan objektif), mengabaikan sejarah (menolak humanisme dan kebebasan tunggal), mempertanyakan rigiditas pembacaan antara ilmu alam (humaniora, ilmu sosial, seni dan sastra, fisksi dan teori, image, dan realitas), serta berfokus pada wacana alternatif (postmodernisme mencoba melihat kembali apa yang telah dibuang, dilupakan dianggap irasional, tidak penting, tradisional, ditolak, dimarginalkan dan disunyikan).

Dari ketiga tahapan atau gelonmbang tersebut, melahirkan berbagai alirann dalam tubuh feminisme itu sendiri Telah disebutkan di awal bahwa gelombang ketiga mencakup empat aliran feminisme, yakni feminisme postmodern, feminisme multikultural, feminisme global, dan ekofeminisme. Seperti masing-masing gelombang dalam feminisme, keempat aliran ini juga saling menegasi,serta melengkapi antara satu dengan yang lainnya. 
Feminisme postmodern bertitik tekan pada teks sebagai dasar berpikirnya. Ia membangun suatu anggapan mendasar bahwa realitas adalah teks, baik yang berbentuk lisan, tulisan, maupun image, yang dalam pengupayaannya nampak berusaha mengkritik cara laki-laki yang diproduksi melalui bahasa laki-laki. Aliran feminisme ini juga menolak cara berpikir yang fanatik atau tradisional. Ia lebih menekankan pada interpretasi yang plural ketimbang subjektifitas. Di samping itu, sebagiamana Gadis Arivia ungkapkan dalam Filsafat Berperspektif Feminisme (2003) bahwa pemikiran feminisme postmodern ini melihat perempuan sebagai “yang lain”. Adapun soal alianasi perempuan, dilihat bersumber dari dua ranah, yakni tekanan atau rasa inferioritas dan cara berada, berpikir serta bahasa. Pengaruh eksistensialisme, psikoanalisa dan dekonstruksi sangat terasa dalam aliran feminisme postmodern. Baginya, perbedaan antara laki-laki dan perempuan harus diterima dan dipelihara.

Bahwa kita harus berusaha membongkar narasi-narasi besar, realitas, konsep kebenaran, dan juga bahasa. Upaya inilah yang kemudian melahirkan beberapa langkah dalam merekonstruksi pengalaman perempuan dalam dunia laki-laki: perempuan harus membentuk bahasanya sendiri; perempuan harus membuat seksualitasnya sendiri; dan harus ada usaha untuk menyimpulkan dirinya sendiri atau dikenal juga dengan undo phallocentric discourse.

Feminisme multikultural senada dengan teori aliran feminisme sebelumnya yang juga melihat individu sebagai sesuatu yang terfragmentasi. Karenanya, feminisme multikultural lebih menyoal ide bahwa ketertindasan perempuan bersumber dari "satu definisi", bukan dari kelas dan ras, preferensi seksual, umur, agama, pendidikan, pekerjaan, kesehatan, dan lain sebagainya. Secara historis, feminisme multikultural pertama kali berlangsung di Amerika Serikat dimana ideologi yang mendukung adanya diversifikasi (ide tentang perbedaan) menjadi pilihan dalam gaya maupun ideologinya. Hingga memasuki abad ke-20, ide asimilasi dan identitas tunggal kemudian menjadi pilihan yang kuat. Hal yang ini 
selanjutnya memberi jalan pada etnisitas sekaligus integrasi, hingga melahirkan multikulturalisme dan berpengaruh kuat pada aliran feminisme multikultural. Hematnya, penyambutan baik terhadap multikulturalisme didasarkan pada pengagungan pada ide perbedaan. Bahwa bagi kalangan feminis multikultural semua orang sesungguhnya berbeda-beda, baik secara kulit, agama, ras dan lain sebagainya.

Selanjutnya, yakni feminisme global. Aliran ini lebih menekankan pada pentingnya melihat ketertindasan perempuan dari "sistem keterkaitan" (interlocking system). Fokus feminisme aliran ini adalah penindasan dunia pertama karena kebijaksanaan nasional yang mengakibatkan penindasan bagi perempuan di dunia ketiga. Hanya saja, jika feminisme multikultural fokus pada rasisme, etnisitas dan kelasisme, feminisme global justru lebih fokus pada isu kolonialisme, di samping soal politik dan ekonomi skala nasional. Mereka sepakat bahwa penindasan politik dan ekonomi lebih diperhatikan. Mereka melihat adanya perbedaan cara pandang antara feminis dunia pertama dengan dunia ketiga. Singkatnya, mereka memandang bahwa setiap perempuan itu berbeda, di setiap komunitas perempuan itu berada juga berbeda; sehingga penindasan yang terjadi pada perempuan mempunyai keunikan dan kondisi yang berbeda pula

Aliran feminisme keempat dari gelombang ketiga adalah ekofeminisme. Aliran ini adalah sebuah gerakan yang berusaha menciptakan dan menjaga kelestarian alam dan lingkungan. Basis gerakan ini adalah femininitas/perempuan. Dalam gerakan ekofeminisme, perempuan dianggap memainkan peran strategis. Semua peran dari perempuan ini berupaya untuk mencegah atau setidaknya menciptakan lingkungan alam yang nyaman dan asri. Seperti halnya feminisme multikultural dan global, ekofeminisme juga memberi pemahaman adanya keterhubungan antara segala bentuk penindasan manusia. Hal ini sebagaimana yang diungkap oleh Carolyn Merchant bahwa ada empat hal yang saling berkaitan di mana peran perempuan menjadi penting, yakni ekologi, produksi, reproduksi dan kesadaran. 
Keseluruhannya diatas dapat dikatakan bahwa meskipun berbeda-beda secara fokus perhatian, baik antara gelombang feminisme maupun antar aliran feminisme, khususnya dalam gelombang ketiga, sejumlah aliran tetap menempatkan perempuan pada posisi yang semestinya. Artinya, dengan pengalaman ketertindasan yang dialami kaum perempuan, kalangan feminis berusaha memberi semangat, dorongan, serta inspirasi tentang pentingya peran dan posisi perempuan, terutama peran dan posisinya dalam ranah kultur maupun politik. Hematnya, cita-cita kebebasan perempuan adalah cita-cita kesetaraan manusia, sekaligus cita-cita kemanusiaan itu sendiri.

\section{GERAKAN SOSIAL}

Gerakan Feminisme adalah salah satu bentuk gerakann sosial uyang dibangun oleh kaum peremuan guna terciptanya keadilan dimuka bumi. Secara umum gerakan sosial di defenisikan oleh maxine Molyneux sebagai sebuah gerakan yang dilakukan untuk meraih tujuan bersama ${ }^{5}$./ Sukanti mengutip pendapatnya Ralph Turner dan Lewis M.Killian mendefenisikan gerakan sosial sebagai suatu kolektivitas yang berlangsung dalam waktu yang agak lama dan yang mempunyai tujuan mengadakan perubahan atau menantang terjadinya suatu perubahan dalam masyarakat

Defenisi yang sama juga disampaikan oleh Giddens mendefinisikan gerakan sosial sebagai suatu upaya kolektif untuk mengejar suatu kepentingan bersama melalui tindakan kolektif (colective action) diluar lingkup lembaga-lembaga yang mapan. 
Gerakan sosial terdiri dari beberapa pendekatan yang terbangun, yaitu : Political Oportunity Structure (POS). Reosurs Mobization Theory (RMT) dan Collectiva action frames.Selain tiga pendekatan ini, masih terdapatb pendekatanpendekatan yang lain dalam sebuahy gerakan sosial, namun tiga pendekatan ini yang sering di gunakan dalam penelitian- penelitian feminisme.

\section{a. Political Oportunity Structure (POS)}

Pada Pendekatan Political Oportunity Structure (POS) atau struktur kesempatan politik menjelaskan bahwa gerakan sosial terjadi karena disebabkan oleh perubahan dalam struktur politik yang dilihat sebagai kesempatan . Perubahan dalam struktur politik tidak semata-mata hanya di pahami pada struktur kelembagaan secara formal, namun struktur politik disini juga termasuk Political Policy yang dibangun oleh sebuah lembaga kenegaraan.

Secara Spesifik Mc Adam dan Tarrow menjelaskan beberapa wariabel yang tentang mekanisme Political Oportunity, yaitu pertama gerakan sosial muncul ketika tingkat akses terhadap lembaga-lembaga politik mengalami keterbukaan. Kedua ketika keseimbangan politik sedangan tercerai berai sedangkan keseimbangan politik baru belum terbentuk. Ketiga, ketika para elit politik mengalami konflik besar dan konflik ini dipergunakan oleh pelaku perubahan sebagai kesempatan. Keempat, ketika para pelaku perubahan digandeng oleh para elit yang berada dalam sistim untuk melakukan perubahan ${ }^{10}$

\section{b. Resource Mobilization Theory}

Teori moblisasi sumber daya menyatakan bahwa munculnya gerakan sosial disebabkan karena tersedianya faktor-faktor pendukung misalnya, faktor koalisi dan dukungan dana, adanya tekanan dan upaya pengorganisasian yang efektif serta seumber daya yang penmting berupa ideologi

Selain itu, teori ini juga berpendapat bahwa gerakan sosial dapat terjadi jika pelakunya 
memiliki akses ke sumber daya yang memungkinkan perorganisasian gerakan. Faktor penyebab gerakan sosial akan selalu ada dalam masyarakat, entah dipicu ketidakpuasan maupun keinginan memeperbaiaki kondisi masyarakat.. Namun, sumber daya yang dibutuhkan untuk tindakan kolektif tidak selalu tersedia.

Dari pendapat tersebut, dapat ditarik suatu pemikiran bahwa teori mobilisasi sumber daya lebih menitik beratkan terjadinya suatu gerakan sosial lebih pada tatanan teknis jika terdapat faktor pendukung, baik secara internal maupun eksternal. Sevara internal dapat diidentifikasi faktor pendukungnya berupa Financial Support ( dukungan dana) dan ideologisasi kepada para pelaku gerakan sosial. Dan secvara eksternal, adanya pemicu ketidak puasan dan penekanan terhadap pelaku gerakan sosial. Dann secara eksternal adanya pemicu ketidak puasan dan penekanan terhadap pelaku gerakan soaisl oleh kekuasaan.

\section{c. Collective Action Frames}

Aksi kolektif merupakan salah satu jenis gerakan sosial. Aksi kolektif sangat berhubungan erat dengan teori perilaku kolektif. Teori perilaku kolektif menjelaskan tentang kemunculan aksi sosial. Aksi Sosial merupakan sebuah gejala aksi bersama yang ditujukan untuk merubah norma dan nilai dalam jangka waktu yang panjang.

Pada sistim sosial seringkali dijumpai ketegangan baik dari luar sistim maupun dari dalam sistim. Ketegangan ini dapat berwujud konflik status sebagai hasil dari diferensiasi struktur sosial yang ada. Teori ini melihat ketegangans ebagai variabel antara yang menghubungkan antara individu seperti peran dan struktur organisasi dengan perubahan sosial.

Ketegangan tersebut dapat melahirkann suatu tindakan atau aksi kolektif dalam

sebuah kelompok. Keteganagn ini terlahir adanya kesenjangan antara apa yang diharapkan dengan apa yang sesungguhnya terjadi. Gur menyatakan bahwa " perilakum kolektif bisa disebabkan oleh rasa ketidaksenangan. Sedangkan rasa 
ketidaksenangan merupakan produk dari lketidak-sesuaian anatar kondisi objektif.

Setiap aksi kolektif senantiasa melibatkan organisasi untuk mendesain aturan-aturan main dan melaksanakan aksi kolektif tyang disepakati, menggalang proses patisipasi, dan menegakan aturan-atuiran yang telah diterima, yang dianggap akan memberikan manfaat bagi kelompok. Aspek mobiliasi adalah aspek yang berkaitan dengan pelaku gerakan (manusia) dan alat rpoduksi. Aspek Opportunity merupakan peluang politik yang akan melahirkan geraka kolekttif itu sendiri

\section{FEMINSIME SEBAGAI GERAKAN SOSIAL}

Dibeberapa negara gerakan feminisme merupakan reaksi dar ragam persoalan yang terjadi seperti ketidakadilan terhadap kaum perempuan,maupun adanya proses penindasan. Kaum perempuan berjuang demi kesetraan hak-hak dan kesempatan yang sama maupun kebebasan untuk mengontrol dan menentukan jalan kehidupan nya sendiri. Reaksi ini diwujudkan oleh kaum perempuan dalam beberapa bentuk gerakan sosial yaitu aksi maupun dalam bentuk tulisan -

tulisan.

Perjuangan perempuan dalam menuntut persamaan hak terjawab sudah dan membuahkan hasil yang memuaskan. Perempuan mendapatkan akses yang sama dengan pria dalam hal pendidikan, pekerjaan, politik dbeberapa aspek kehidupan bermasyarakat. Namun bukan serta merta kaum perempuan dan pria sudah setara. Di beberapa negara, tubuh perempuan masih dianggap objek, hal ini bisa terlihat pada iklan-iklan yang mengekspos sebagian tubuh perempuan yang dianggap seksual, ditambah lagi dengan isu pemerkosaan, kekerasan seksual dan kekerasan dalam rumah tangga masih saja sering terdengar.

Konsep Feminsime dapat di katakan sebagai bentuk perubahan sosial dan bentuk perlawanan sosial dengan kata lain feminisme merupakan sebuah gerakan yang memiliii tujuan untuk mendapatkan kesetaraan ndan kedudukan hak yang sama dengan laki-laki. Gerakan feminisme bukan sekedar bentuk 
perlawanan terhadap laki laki melainkan bentuk perlawanan pada tatanan sosial yangm menganggap bahwa laki-laki meiliki derajat yang lebih tinggi. Gerakan feminisme hadir untuk mendobrak sistim sosial yang dimana laki-laki memilikim kekuasaan penuh atau mendominasi terhadap perempuan. Sistim dominasi laki laki atas perempuan yang biasa disebut budaya Patriarki.

Intinya adalah gerakan feminisme bertujuan untuk membuat perubahan akan ketidakadilan sistim soaial, bahwa laki-laki dan perempuan sejatinya memiliki hak yangsama maka dari itu sesungguhnya int8i perjuangan gerakann feminismi adalah equality atau kesetaraan.

\section{PENUTUP}

Feminisme merupakan salah satu gerakan sosial yang terdiri dari kaum perempuan . Gerakan sosial ini bertujuan untuk mendapatkan keseimbangan dan persamaan hak- hak anatar perempuan dan laki -laki. Dengan adanya gerakan sosial feminsime bisa merobah prinsp Patriarki yang mendominasikan derajat laki-laki lebih tinggi dari perempuan sehingga pada ahirnya kesewenangan terhadap perempuan bisa berkurang.

\section{DAFTAR PUSTAKA}

AM.Thufail AM,2007, Memperjuangkan Keadilan Gender: Gerakan Perempuan Menuju Civil Society, dalam buku IPerempuan Agama dan Demokrasi,Yogyakarta: LSIP

Fakih ,Mansur Fakih . 2009, Gerakan Sosial Aktivisme Gemkara-BP3KB dan pengaruhnya Dalam Mewujudkan Kabupaten Batu Bara (Skripsi) Medan, Universitas SumateraUtara Medan

Jackson Stevi Jackson ,2009 . (ed)Pengantar teori teori feminism Kontemporer, Yogyagarta: Jalasutra,

Lestari, Indah, 2006. Katakkan dan Lawan : Bahasa dan Perjuangan Feminisme dalam Teori Julla

Kristeva, Jurnal Perempuan 
Muhtadi.Burhanudin ,2011,Demokrasi Zonder Toleransi Potret Islam Pasca Orde

Baru :Makalah, Nugroho,Kharisma dan Kwan Men Yon, 2011. Pengurangan resiko

Bencana Berbasis Komunitas

di Indonesia Gerakan Pelembagaan dan Berkelanjutan ,Artikel

Suharto,2006. Gerakan Sosial Baru di Indonesia: Repertoar Gerakan petani (Jurnal Ilmu Sosial dan Ilmu Politik.

Suryochondr .Sukanti,1984. Potret Pergerakan Wanita diIndonesia, jakarta:Rajawali

Wahyudi, 2005. Farmasi dan Struktur Gerakan Sosial Petai Studi Kasus Reklaming/Penjarahan atas tanah PTPN ( persero) Kalibakar Malang Selatan. Malang: UMM PresS.

Wahib Situmorang. Abdul,2007. Gerakan Sosial Studi Kasus Beberapa Perlawanan Yogjakarta: Pustaka Pelajar,

http//id/wikipedia.org/wiki/Feminisme ( diakses tanggal 30 juli 2019 jam 12.50 wit)

http//avatarpower.blogspot.com/2009/06/teori-kolektif.html (akses tanggal 05 agustus 20 JAM15.03 